\title{
Comparative Analysis of Nuclear Power Plant and Thermal Power Plants Using Analytic Hierarchy Process (AHP)
}

\author{
Yanuar Z. Arief \\ (1)Dept. of Electrical and Electronic Eng., \\ Faculty of Engineering \\ Universiti Malaysia Sarawak (UNIMAS) \\ Kota Samarahan,, Sarawak, Malaysia \\ ayzulardiansyah@unimas.my \\ (2) Master of Engineering Program, \\ Department of Electrical Engineering, \\ Faculty of Engineering, \\ Jakarta Global University (JGU), \\ Grand Depok Citi, Jl. Boulevard Raya 2, \\ Tirtajaya, Sukmajaya, Kota Depok, \\ Indonesia
}

\author{
Erdawaty Samsul \\ Dept. of Electrical and Electronic Eng., \\ Faculty of Engineering \\ Universiti Malaysia Sarawak (UNIMAS) \\ Kota Samarahan,, Sarawak, Malaysia \\ erdawatysamsul@gmail.com \\ Hamzah Eteruddin \\ Dept. of Electrical Engineering, \\ Faculty of Engineering \\ Universitas Lancang Kuning (UNILAK), \\ J1. Yos Sudarso, KM 8 Rumbai, \\ 28265 Rumbai, Riau, Indonesia \\ hamzah@unilak.ac.id
}

\author{
Mohd Hafiez Izzwan Saad \\ Dept. of Electrical and Electronic Eng., \\ Faculty of Engineering \\ Universiti Malaysia Sarawak (UNIMAS) \\ Kota Samarahan,, Sarawak, Malaysia \\ smhizzwan@unimas.my
}

\begin{abstract}
In Malaysia, fossil fuels are the most frequently used as energy resource. However, the amount of reserves for fossil fuels is now declining. That is why nuclear energy has become more popular for a certain country to diversify its production of energy. The aim of this paper is to analyze the suitability of nuclear power plant (NPP) compared to conventional power plants using a multi-criteria decision-making technique or known as the Analytic Hierarchy Process (AHP). A framework of AHP's hierarchy is being developed, and the hierarchy structure consists of six criteria, namely safety and security, resources, public acceptance, cost of energy, construction time, and $\mathrm{CO}_{2}$ emission, respectively. Other than that, three alternatives, namely NPP, thermal power plant and hydropower plant, are also considered in the hierarchy structure. By using AHP technique, the system reveals that the hydropower plant is the most favourable choice of a better power plant compared with others. The results obtained demonstrate the validity of the framework developed.
\end{abstract}

Keywords-Nuclear power plant, thermal power plants, analytic hierarchy process, criteria, alternative, goal, consistency ratio, consistency index.

\section{INTRODUCTION}

The supply of electricity is essential in this era of globalization and modern life where the energy demand is increasing every day and the government of each country must be able to meet this growing demand for energy. In Malaysia, the main sources of power generation or electricity output used basically generated from fossil fuel such as coal, diesel fuel, natural gas and etc which have huge consequences for the environment. Thus, Malaysia should ready to substitute the non-renewable energy to renewable and alternatives energy sources like hydropower and nuclear in the future. This is because nuclear power plants does not lead to air pollution as it does not produce emission of poisonous gases such as nitrogen oxide and sulfur dioxide that will lead to man-made disasters like acid rain and global warming [1].

The sources of nuclear power plants come from uranium and originate from the separation of uranium atoms known as the fission process. From that process, it generates heat to produce steam that will drive the turbine to produce electricity. In order to know and select a better source to generate power in Malaysia, there are certain criteria that must be considered. Analytic Hierarchy Process (AHP) is utilized in order to have a great decision. AHP is an effective tool to handle complex decision making [2].

This method was developed by Thomas Saaty at the Wharton School of Business and it has proved the potential of the system used for decision making in managerial problems [3]. These multiple criterion decision-making tools are set up in a hierarchical structure. It is a method of decision-making that helps the decision-makers to make the right decision through the decision making process [4]. The AHP is a strong weighted scoring system that assists in setting goals, evaluating and making the best decision [5].

Nuclear power plant has become an important part of the energy balance in the world. Nowadays, global energy consumption is increasing significantly as the population increases. Hence the government of each country must be able to supply this growing energy demand for their peoples. Everyone must understand that nuclear is not only a factor in creating explosive energy but also in generating electricity [6]. Nuclear power plants (NPP) generate fewer gas emissions for each unit of energy it produces compared with conventional power plants like fossil fuels, including coal and natural gas. There are currently around 440 reactors operating in 30 countries, with a total net install capacity is 389.34 GWe [7]. Table 1 shows the number of reactors in each country with its total net electrical capacity based on the world statistics from the International Atomic Energy Agency (IAEA) website.

Currently, the largest number of operating nuclear units (95) and the highest installed capacity (97,154 MW) is in the United States (US). Next is France with 56 units, and the installed capacity is $61,370 \mathrm{MW}$, then China with 48 units and 45,518 MW installed capacity, followed by Russia with 38 units and 28,437 MW installed capacity. Japan has 33 operating units with 31,679 MW installed capacity. The Republic of Korea has 24 units and 23,172 MW installed 